\title{
R- AND G-BAND PATTERNS IN Astyanax scabripinnis paranae (PISCES, CHARACIFORMES, CHARACIDAE)
}

\author{
Edson Luis Maistro ${ }^{1}$, Fausto Foresti ${ }^{2}$ and Claudio Oliveira ${ }^{2}$
}

\begin{abstract}
The absence of longitudinal bands in fish chromosomes has been associated with technical problems in chromosome preparations or the absence of a structural compartmentalization in the fish genome. In the present study, a R-banding pattern was obtained using a replication banding technique by in vivo treatment with 5-bromodeoxyuridine (5-BrdU). G-banding patterns were obtained after trypsin treatment and also after chromosome cleavage by in situ treatment with the restriction endonuclease BamHI. A similar G-banding pattern was also obtained after cleavage with the endonuclease Hinfl. Presence of a resolute R- and G-banding patterns shows that Astyanax scabripinnis paranae chromosomes could present an isochore-like structure similar to that found in other vertebrates.
\end{abstract}

\section{INTRODUCTION}

Although some cytogenetic techniques have been applied successfully to fish, such as Ag-NOR and C-banding, G- or R-bands are usually very laborious to obtain, with frequently poor results. The absence of longitudinal bands in fish chromosomes has frequently been associated with the absence of structural compartmentalization in the fish genome (Medrano et al., 1988; Schmid and Guttenbach, 1988) or with technical problems in chromosome preparations (Gold et al., 1990). The aim of this study was to investigate the possible existence of a resolute chromosome banding pattern in the normal diploid genome and B-chromosomes of Astyanax scabripinnis paranae.

\section{MATERIAL AND METHODS}

Cytogenetic studies were conducted on eight individuals (four females and four males) of an A. scabripinnis paranae population collected from Cascatinha Stream, Botucatu, São Paulo, Brazil, which presents $2 \mathrm{n}=50$ chromosomes and one macro B-chromosome (Maistro et al., 1994).

Chromosome spreads were obtained as described by Foresti et al. (1993). In order to obtain a replication banding pattern (R-band), three animals were injected with $1 \mathrm{ml} / 100 \mathrm{~g}$ body weight of a $0.05 \%$ solution of 5 bromodeoxyuridine (5-BrdU) $6.5 \mathrm{~h}$ prior to chromosome preparation from a cell suspension (Almeida-Toledo et al., 1988). Slides were analyzed after FPG staining (ISCN, 1978). For G-banding, slides previously stored for about three days at room temperature were incubated in $2 \mathrm{x}$ SSC

${ }^{1}$ Instituto de Farmácia e Nutrição, Universidade de Alfenas, 37130-000 Alfenas, MG, Brasil.

${ }^{2}$ Departamento de Morfologia, Instituto de Biociências, UNESP, 18618OOO Botucatu, SP, Brasil and CAUNESP, Jaboticabal, SP, Brasil. Send correspondence to E.L.M. for $2 \mathrm{~h}$ at $60^{\circ} \mathrm{C}$, and treated/stained in a trypsin/Giemsa solution for $10 \mathrm{~min}$ at room temperature (Gold et al., 1990, modified by Bertollo et al., 1997 for fish chromosomes). For treatment with restriction endonucleases (REs), the enzymes were suspended in appropriate buffer and applied at the following concentrations and times: a) BamHI 2.0 $\mathrm{U} / \mu \mathrm{l}$, for $4 \mathrm{~h}$; b) HinfI $1.0 \mathrm{U} / \mu \mathrm{l}$, for $4 \mathrm{~h}$. Slides were incubated in a moist chamber at $37^{\circ} \mathrm{C}$, washed in distilled water and stained with $5 \%$ Giemsa for 7 min. Representative metaphases were karyotyped for all individuals.

\section{RESULTS AND DISCUSSION}

Replication banding patterns have been obtained for several fish species (Delany and Bloom, 1984; AlmeidaToledo et al., 1988; Giles et al., 1988; Gold et al., 1990; Hellmer et al., 1991; Sánchez et al., 1993; Bertollo et al., 1997) after brief treatment with BrdU. A replication banding pattern was obtained in chromosome preparations of A. scabripinnis paranae using this technique (Figures 1a and 2a).

Consistent G-banding patterns have been described for the chromosomes of Anguilla anguilla (Wiberg, 1983), Opsopoeodus emiliae (Gold et al. 1990), Oncorhynchus mykiss and O. kisutch (Abuín et al., 1996) and Hoplias malabaricus (Bertollo et al., 1997). In the present study, G-banding patterns were obtained for chromosomes of $A$. scabripinnis paranae after trypsin treatment and BamHI treatment (Figures 1b-c, 2b-c). The cleavage with the RE HinfI also resulted in a longitudinal differentiation pattern on the chromosomes which differed from normal G-banding patterns only by the fact that some heterochromatic regions were also digested (Figures 1d, 2d).

Analysis of R- and G-banding patterns revealed a pattern of longitudinal differentiation also in the macro Bchromosomes of A. scabripinnis paranae from the Cascatinha Stream. The macro B-chromosome identified in this population is similar in size to the first pair in the karyotype of the individuals (Maistro et al., 1994). Similar ob- 


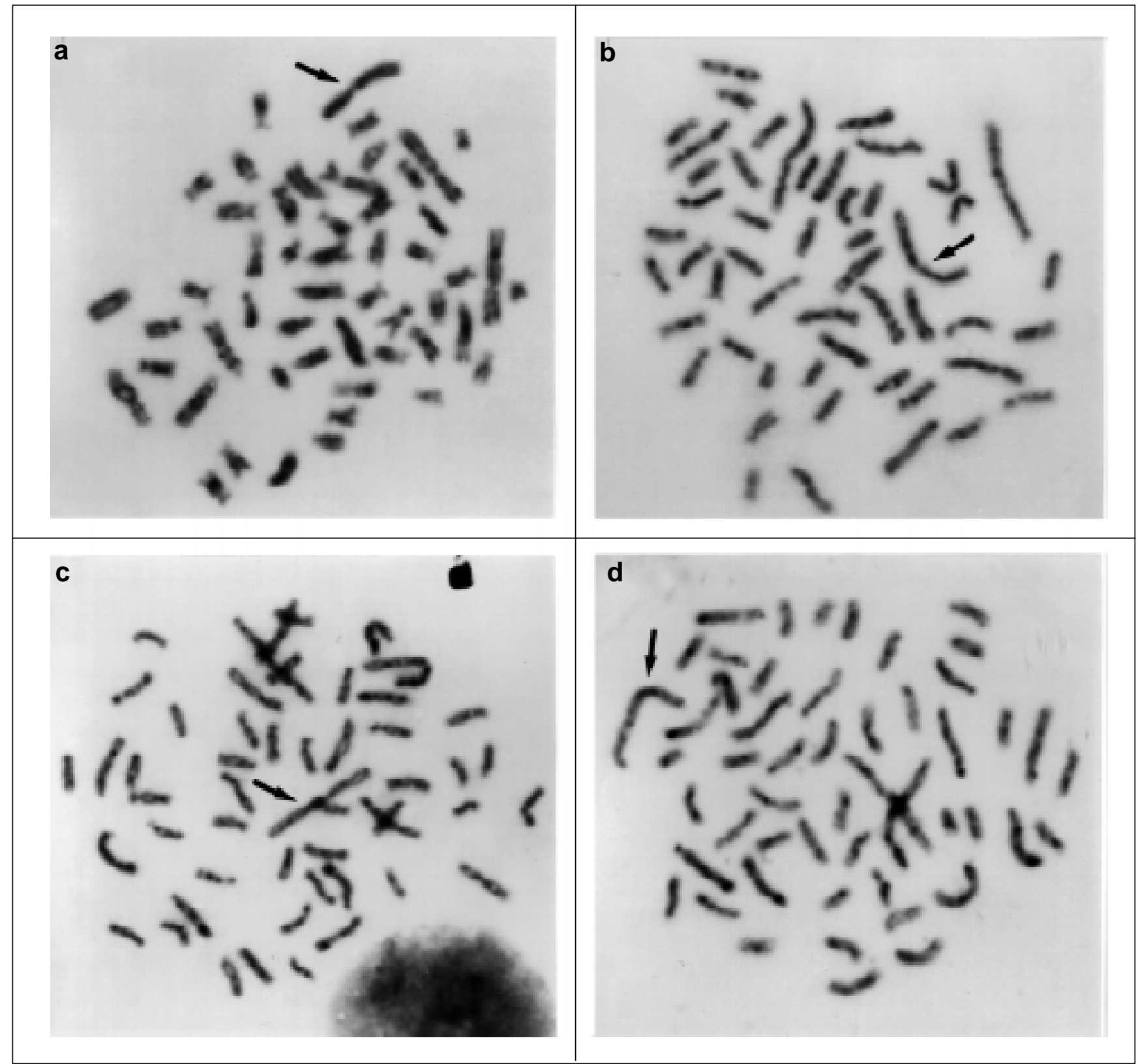

Figure 1 - Somatic metaphase chromosomes of Astyanax scabripinnis paranae submitted to different banding procedures: (a) replication banding pattern (R-band) after treatment with 5-BrdU; (b) G-banding pattern obtained after trypsin treatment; (c) G-banding pattern obtained after chromosome cleavage by in situ treatment with the restriction endonuclease BamHI, and (d) similar G-banding pattern obtained after cleavage with the restriction endonuclease HinfI. Arrows mean probable B-chromosomes.

servations were made in other populations of A. scabripinnis (Salvador and Moreira-Filho, 1992; Maistro et al., 1992; Fauaz et al., 1994, among others). However, the R- and G-banding patterns observed in B-chromosomes in this study were different from those obtained for the first chromosome pair of the A complement. Thus, the B-chromosome of A. s. paranae may have originated by chromosomal non-disjunction of the first metacentric pair in the meiotic process (see Beukeboon, 1994), first appearing as a trisomic element, and then following its own evolutionary pathway. Alternatively, the B-chromosome may have originated by amplification of other chromosome segments.

According to Lópes-Fernandez et al. (1991), most REs, recognizing 4-5-base pairs (bp), induce C-bands (sometimes associated with G-bands) in chromosomes subsequently stained with Giemsa and/or DNA-specific dyes. On the contrary, G-like bands are produced in chromosomes digested with certain 6-bp cutters and subsequently stained with Giemsa but not DNA-specific dyes. G-band production has been interpreted as the consequence of differential accessibility of REs to different chromosome regions (Gosálvez et al., 1997). The present results 


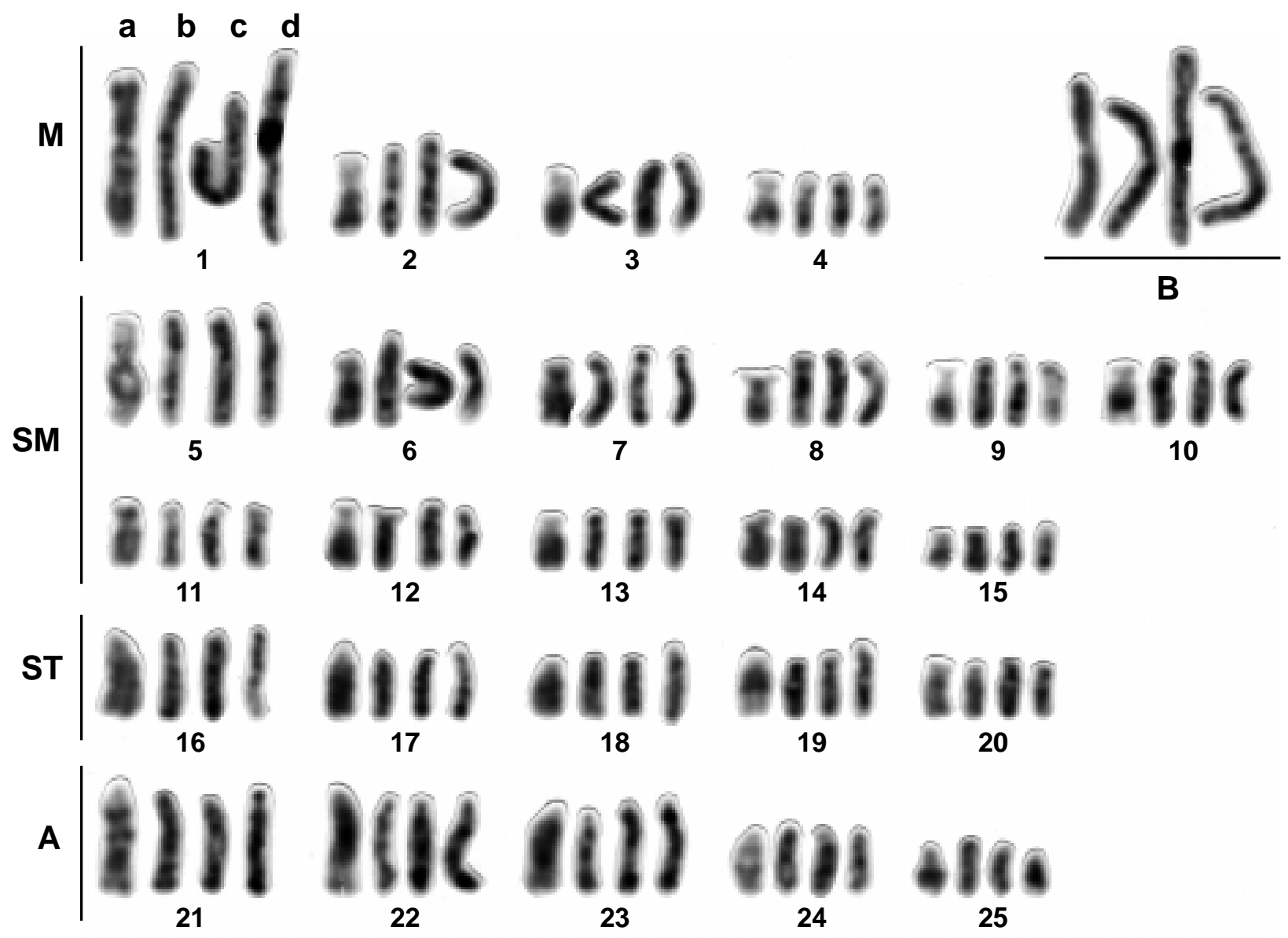

Figure 2 - Haploid chromosome sets of Astyanax scabripinnis paranae showing different patterns of longitudinal differentiation after being submitted to banding procedures: (a) R-banding; (b) G-banding with trypsin; (c) G-banding after treatment with RE BamHI, and (d) almost similar G-banding patterns obtained with RE HinfI. B, B-chromosomes. M, Metacentric; SM, submetacentric; ST, subtelocentric; A, acrocentric.

confirm those postulated by the above authors, since RE Bam HI recognizes a sequence of 6-bp (5'-G $\downarrow$ GATCC-3') and produces a G-like banding pattern, and the RE HinfI recognizes a sequence of 5-bp (5'-G $\downarrow$ ANTC-3') and produces a G-like banding pattern.

It has been suggested that the chromosomes of many species of cold-blooded vertebrates show only poor or no G-banding, although they may show a replication banding pattern (Cuny et al., 1981; Medrano et al., 1988; Schmid and Guttenbach, 1988; Bernardi, 1989; Bernardi, 1995). In the present study specific and reproducible Rbanding and G-banding patterns were obtained in all metaphases of A. scabripinnis paranae with decondensed chromosomes; however, they could not be identified in metaphases with condensed chromosomes. These data associated with recent reports of G-banding in cold-blooded vertebrates (Abuín et al., 1996; Bertollo et al., 1997) are in accordance with the hypothesis that the failure to detect chromosome banding in fish chromosomes is due more to technical problems in the use of banding protocols than to the total absence of a structural compartmentalization in the fish genome.
The existence of a correspondence between the results obtained with R-banding and G-banding techniques shows that the longitudinal differentiation bands of the chromosomes correspond to real structural units in the genome of A. scabripinnis paranae. Similar results were obtained by Bertollo et al. (1997) studying Hoplias malabaricus chromosomes, where the G- and replication banding patterns, together with $\mathrm{C}$-banding, permitted not only a good characterization of the $\mathrm{X}_{1}$ and $\mathrm{Y}$ chromosomes but also identification of the rearrangements that occurred in the establishment of the $\mathrm{X}_{1} \mathrm{X}_{2} \mathrm{Y}$ sex chromosome system. The presence of replication banding patterns in fish chromosomes indicates that chromosome replication is temporally clustered into early- and late-replicating units, leading to a distinct replication banding pattern on each chromosome (Sánchez et al., 1993), which is comparable to the situation found in warm-blooded vertebrates. The presence of resolutive R- and G-banding patterns shows that the chromosomes of $A$. scabripinnis paranae could present an isochore structure similar to that found in other vertebrates. The use of such methodology in fish cytogenetics could be an important tool for the study of karyo- 
type evolution and mechanisms of chromosome diversification in fish, although detection of multiple structural bands in fish chromosomes continues to be a field requiring further studies.

\section{ACKNOWLEDGMENTS}

The authors are grateful to Mr. Renato Devidé for technical assistance and to Dr. Luiz A.C. Bertollo for help in refining the G-banding technique. Research supported by FUNDUNESP, CNPq and FAPESP. Publication supported by FAPESP.

\section{RESUMO}

A ausência de bandas longitudinais em cromossomos de peixes tem sido associada a problemas técnicos nas preparações cromossômicas ou à ausência de uma compartimentalização estrutural no genoma dos peixes. No presente estudo, um padrão de bandas $\mathrm{R}$ foi obtido usando a técnica de bandamento de replicação pelo tratamento in vivo com 5-BrdU. Padrões de bandamento $\mathrm{G}$ foram obtidos após tratamento dos cromossomos com tripsina e também após clivagem in situ com a endonuclease de restrição BamHI. Um padrão similar de bandamento G também foi obtido após clivagem dos cromossomos com a endonuclease HinfI. A presença de um resolutível padrão de bandamento R e G em Astyanax scabripinnis paranae mostra que seus cromossomos parecem apresentar estrutura "isochore" similar àquela encontrada em outros vertebrados.

\section{REFERENCES}

Abuín, M., Martínez, P. and Sánchez, L. (1996). G-like banding pattern in two salmonid species: Oncorhynchus mykiss and Oncorhynchus kisutch. Chromosome Res. 4: 471-473.

Almeida-Toledo, L.F., Viegas-Pequignot, E., Foresti, F., Toledo-Filho, S.A. and Dutrillaux, B. (1988). BrdU replication patterns demonstrating chromosome homoeologies in two fish species, genus Eigenmannia. Cytogenet. Cell Genet. 48: 117-120.

Bernardi, G. (1989). The isochore organization of the human genome. Аnnи. Rev. Genet. 23: 637-661.

Bernardi, G. (1995). The human genome: organization and evolutionary history. Annu. Rev. Genet. 29: 445-476.

Bertollo, L.A.C., Fontes, M.S., Fenocchio, A.S. and Cano, J. (1997). The $\mathrm{X}_{1} \mathrm{X}_{2} \mathrm{Y}$ sex chromosome system in the fish Hoplias malabaricus. I. G-,
C- and chromosome replication banding. Chromosome Res. 5: 493-499.

Beukeboom, L.W. (1994). Bewildering Bs: an impression of the 1st Bchromosome Conference. Heredity 73: 328-336.

Cuny, G., Soriano, P., Macaya, G. and Bernardi, G. (1981). The major components of the mouse and human genomes: preparation, basic properties and compositional heterogeneity. Eur. J. Biochem. 111: 227-233.

Delany, M.E. and Bloom, S.E. (1984). Replication banding patterns in the chromosomes of the rainbow trout. J. Hered. 75: 431-434.

Fauaz, G., Vicente, V.E. and Moreira-Filho, O. (1994). Natural triploidy and $\mathrm{B}$ chromosomes in the neotropical fish genus Astyanax (Characidae). Braz. J. Genet. 17: 157-163.

Foresti, F., Oliveira, C. and Almeida-Toledo, L.F. (1993). A method for chromosome preparations from large fish specimens using in vitro short-term treatment with colchicine. Experientia 49: 810-813.

Giles, V., Thode, G. and Alvarez, M.C. (1988). Early replication bands in two scorpion fishes, Scorpaena porcus and $S$. notata (order Scorpaeniformes). Cytogenet. Cell Genet. 47: 80-83.

Gold, J.R., Li, Y.C., Shipley, N.S. and Powers, P.K. (1990). Improved methods for working with fish chromosomes with a review of metaphase chromosome banding. J. Fish Biol. 37: 563-575.

Gosálvez, J., López-Fernandez, C., Goyanes, V. and Mezzanotte, R. (1997). Chromosome differentiation using nucleases: an overview. In: Chromosomes Today (Henriques-Gil, N., Parker, J.S. and Puertas, M.J., eds.). Vol. 12. Chapman \& Hall, London, pp. 23-49.

Hellmer, A., Voiculescu, I. and Schempp, W. (1991). Replication banding studies in two cyprinid fishes. Chromosoma 99: 524-531.

ISCN (1978). An international system for human cytogenetic nomenclature. Cytogenet. Cell Genet. 21: 309-404.

López-Fernandez, C., Gosálvez, J., Ferrucci, L. and Mezzanotte, R. (1991). Restriction endonucleases in the study of eukaryotic chromosomes. Genetica 83: 257-274.

Maistro, E.L., Foresti, F., Oliveira, C. and Almeida-Toledo, L.F. (1992). Occurrence of macro B chromosomes in Astyanax scabripinnis paranae (Pisces, Characiformes, Characidae). Genetica 87: 101-106.

Maistro, E.L., Foresti, F. and Oliveira, C. (1994). New occurrence of a macro B-chromosome in Astyanax scabripinnis paranae (Pisces, Characiformes, Characidae). Braz. J. Genet. 17: 153-156.

Medrano, L., Bernardi, G., Couturier, J., Dutrillaux, B. and Bernardi, G. (1988). Chromosome banding and genome compartmentalization in fishes. Chromosoma 96: 178-183.

Salvador, L.B. and Moreira-Filho, O. (1992). B chromosomes in Astyanax scabripinnis (Pisces, Characidae). Heredity 69: 50-56.

Sánchez, L., Abuín, M. and Amaro, R. (1993). Cytogenetic characterization of the AS cell line derived from the Atlantic salmon (Salmo salar L.). Cytogenet. Cell Genet. 64: 35-38.

Schmid, M. and Guttenbach, M. (1988). Evolutionary diversity of reverse (R) fluorescent chromosome bands in vertebrates. Chromosoma 97: 101-114.

Wiberg, U.H. (1983). Sex determination in the European eel (Anguilla anguilla L.). Cytogenet. Cell Genet. 36: 589-598.

(Received November 10, 1997) 